DOI: https://doi.org/10.24144/2409-6857.2021.1(57).90-97

УДК 332.13:352

\author{
Чубарь О. Г., Машіко К.С., Траньович Ю.П.
}

\title{
РОЛЬ ПАРТНЕРСЬКИХ ВІДНОСИН У РОЗБУДОВІ СПРОМОЖНОСТІ ГРОМАДИ: СУТНІСТЬ ТА ПІДХОДИ ДО ОЦІНЮВАННЯ
}

\begin{abstract}
Метою статті $\epsilon$ дослідження партнерських відносин як таких, щзо підвищують спроможність вдосконалювати та розвивати громаду окремими жителями чи групами, які взаємодіють між собою. Представлено огляд результатів закордонних досліджень з визначення спроможності громад та підходів до ї̈ оцінювання, окреслено місие партнерства та співпраці в нарощуванні потенціалу громади. Розвинуто підходи щооо визначення сутності партнерської спроможності громад з виділенням основних факторів впливу на неї, а також критеріїв очінки результативності партнерських відносин.

Ключові слова: громада, оцінка спроможності громади, партнерство, синергія партнерства, партнерська спроможність громади.
\end{abstract}

Постановка проблеми. Спроможність громади, в т.ч. партнерська іiї складова, передбачають такі зрізи: здатність громади визначати свої проблеми, здатність громади розробляти спільні заходи для їх вирішення та здатність мобілізувати ресурси для реалізації змін. Більш вузьке розуміння партнерської спроможності охоплює розробку, координацію та супровід спільних заходів для сприяння цим змінам. Тобто вирішення певних проблем у громаді потребує певного рівня спроможності. При цьому для формування та підвищення спроможності громади часто створюють та підтримують партнерства за участі представників громад, іiі організацій та мешканців [7, С. 27].

Водночас, гетерогенність суспільства, бачення i вигоди від співпраці, існування різних політичних груп і зацікавлених осіб, наявні ресурси, компетенція i досвід - це лише невеликий перелік передумов ефективності співпраці. Така комплексна проблема цікава 3 одного боку дослідникам, які потребують способу виміряти результат функціонування партнерства, щоб визначити як працює співпраця, і перевірити припущення про існування переваг від співпраці. 3 іншого боку-учасники партнерства і донори

(C) Чубарь О. Г., к.е.н., доцент, доцент кафедри фінансів і банківської справи, ДВНЗ «Ужгородський національний університет», м. Ужгород, e-mail: oksana.chubar@uzhnu.edu.ua Машіко К.С., к.е.н., заступник директора 3 наукової роботи, Закарпатський регіональний центр соціально-економічних і гуманітарних досліджень НАН України, м. Ужгород, e-mail: ekaterinna333@gmail.com

Траньович Ю.П., м.н.с., Закарпатський регіональний центр соціально-економічних i гуманітарних досліджень НАН України, м. Ужгород, e-mail: julia.tranovych@gmail.com прагнуть розуміти чи дають зусилля результат, які фактори впливають на здатність партнерства досягати результату і як зміцнити партнерства $[9$, C.182].

Аналіз останніх досліджень і публікацій. Світова практика оцінки спроможності громад виділяе широкий спектр факторів, що іiі визначають. Вони охоплюють не тільки матеріальні активи, а і такі як співучасть (англ. participation), лідерство, організаційні структури, зв'язки з іншими, роль зовнішніх агентів, що в свою чергу породжує партнерські відносини в громаді. Такі підходи до визначення потенціалу громади використовуються у працях Easterling D., Goodman R. M., Bopp M., Chaskin R. J., Labonte R., Laverack G., Gibbon M. Роль співпраці у нарощуванні спроможності громади визначається у роботах Ssu-Hsien Chen, Richard C. Feiock, Allison L. Kemner. R.D. Lasker, E.S. Weiss, R. Miller, Taylor-Powell E., B. Rossing, J. Geran, Zhang Xueqing розкривають можливі методи оцінки ефективності співпраці.

Ціллю даної статті $€$ виявлення та узагальнення підходів до оцінки впливу партнерських відносин та співпраці на потенціал громади через визначення факторів партнерської спроможності громад.

Опис основного матеріалу дослідження.

Місие партнерської співпраиі серед компонентів спроможності громади

Існує значна кількість закордонних досліджень, у яких визначається спроможність громади та обговорюються підходи до іiі оцінки (Goodman R. M., Hawe P., Gibbon M., Labonte R., Laverack G.). У літературі йдеться про те, як можна цілеспрямовано нарощувати спроможність громади в контексті програми чи проєкту, а також через взаємовідносини між урядовими та неурядовими організаціями, працівниками та членами громади [11]. 
У науковій літературі є розбіжності щодо того, чи спроможність громади є узагальненою якістю, чи стосується лише конкретних завдань або проблем. Багато авторів визначають спроможність громади частково за допомогою переліку елементів або доменів (Easterling D., Goodman R. M., Bopp M., Chaskin R. J., Laverack G., New South Wales Health Department). На сьогодні немає доказів того, що будь-яка окрема концептуалізація явно краща за інші. Не існує остаточного набору характеристик, які описують спроможну громаду; але вони не можуть безмежно відрізнятися по кожній громаді чи ситуації [8, С. 117].

У своєму дисертаційному дослідженні Laverack G. визначив та інтерпретував дев'ять доменів для підвищення спроможності громади: співучасть, лідерство, організаційні структури, оцінка проблеми, мобілізація ресурсів, «питання чому», партнерство, роль зовнішніх агентів, управління програмами [10].

В подальшому дослідники активно апробовували, уточнювали та наповнювали ці домени індикаторами. $\mathrm{y}$ своїй оцінці спроможності громади Gibbon М. [4] використовувала набір 3 восьми доменів, подібних до тих, що були розроблені Laverack G., а саме: представництво, лідерство, організаиія, оцінка потреб, наявність ресурсів, впровадження, зв'язки, управління. Було визначено набір показників та присвоєно ранг для кожного показника від (1) низького до (4) високого. Це дало можливість зацікавленим сторонам відслідковувати динаміку програм на різних стадіях їх реалізації.

Подібну типологізацію було визначено дослідниками, що вивчали програми фінансування Агентства громадського здоров'я Канади. Було встановлено сфери, в яких місцеві зусилля могли б мати помітний і вимірюваний вплив протягом відносно короткого часу: співучасть; лідерство; громадські структури; «питання чому»; мобілізація ресурсів; зв'язки 3 іншими; роль зовнішньої підтримки; навички, знання та навчання; почуття спільності. Для кожної із сфер-доменів обгрунтовано індикатори, на основі яких розроблено анкету-опитувальник iз 44 питаннями [12, С. 301].

У дослідженні Goodman et al. складовими потенціалу громади, які перебувають у тісному взаємозв'язку між собою $\epsilon$ : співучасть та лідерство, навички, ресурси, соціальні та міжорганізаційні мережі, почуття спільності, розуміння історії громади, влада громади, цінності громади та критична рефлексія. Наприклад, співучасть громадян отримує таке підсилення від інших доменів: лідерство впливає на напрямок та структуру учасників, сприяє підтримці бази учасників, усуває бар'єри та надає можливості для співучасті; навички впливають на якість зустрічей, на планування заходів, обумовлюють задоволеність членів плануванням та діями; наявність ресурсів допомагає залучити учасників, стимулює внески від громадян; соиіальні і міжорганізаційні мережі збільшують вигоду, яку громадяни отримують від співучасті, сприяють частоті / інтенсивності участі тощо [6, C. 264].

Колектив авторів (Bowen G., Martin J., Mancini J., Nelson J.) [2] при визначенні спроможності громади також зробив акцент на взаємовідносинах, a не на ресурсах. Спроможність громади автори визначали як міру, в якій члени громади а) демонструють почуття спільної відповідальності за загальний добробут громади та іï жителів, і б) демонструють колективні вміння у використанні можливостей для задоволення потреб громади та протистояння ситуаціям, які загрожують безпеці та добробуту членів громади.

Викладений вище огляд зарубіжних досліджень і публікацій з проблематики розвитку спроможності громад відображає матеріали кінця 90-х років XX-го століття, а також дослідження п'яти-трьохрічної давності. Тобто у світі питання розвитку громад та їх спроможності представляють науковий і практичний інтерес не менше 20 останніх років. Щодо України, то термін «спроможна територіальна громада» в національному правовому полі, наукових $\mathrm{i}$ прикладних дослідженнях з'явився відносно недавно. Практично це відбулося 3 початком розбудови децентралізаційних процесів та 3 моменту прийняття Закону України «Про добровільне об'єднання територіальних громад» [18] (2015 рік) і розробки Методики формування спроможних територіальних громад [19] (2015 рік). Саме цими нормативними документами дано визначення спроможної територіальної громади. В оновленій редакції Методики від 24 січня 2020 року оцінка рівня спроможності громад проводиться на основі критеріїв, що характеризують основні соціально-економічні показники, які впливають на розвиток відповідної територіальної громади. Такими критеріями є: чисельність населення, що постійно проживає на території спроможної територіальної громади; чисельність учнів, що здобувають освіту в закладах загальної середньої освіти, розташованих на території спроможної територіальної громади; площа території спроможної територіальної громади; індекс 
податкоспроможності бюджету спроможної територіальної громади; частка місцевих податків та зборів у доходах бюджету спроможної територіальної громади [19].

У публікації [16] виділено складові поняття «спроможна територіальна громада» (потенційні та функціональні), розкрито їх основний зміст. До потенційних, які вважаються важливою умовою для здійснення ефективного місцевого самоврядування та забезпечення життєдіяльності громади, віднесені:

- наявність необхідної інфраструктури;

- наявність достатніх фінансових ресурсів та джерел їх утворення;

- наявність кваліфікованих людських ресурсів (кадрів);

- наявність певного обсягу повноважень у представницького органу місцевого самоврядування (місцевої ради), обраного громадою;

- наявність активно налаштованої частини територіальної громади, які беруть участь у вирішенні низки питань їі життєдіяльності.

До функціональних ознак віднесено:

- дієвий вплив активної частини територіальної громади на діяльність органу місцевого самоврядування та його посадових осіб;

- $\quad$ реальне вирішення переважної більшості питань місцевого значення, що належить до компетенції відповідної ради, у т.ч. й через надання низки публічних послуг членам територіальної громади.

Значимість цих ознак полягає у тому, що громада повинна ефективно використовувати не лише свій місцевий потенціал у вигляді майна, фінансів, людських ресурсів (кадрів), повноважень, але й інструменти впливу на органи місцевого самоврядування та їх посадових осіб, здійснювати повноцінне місцеве самоврядування та забезпечувати потреби мешканців відповідних населених пунктів [16, С. 39].

В аналітичній доповіді [17] наголошується на важливості «... переходу від звуженого розуміння поняття дієздатності громад, яке традиційно описується забезпеченістю відповідними ресурсами та здатністю ефективно використовувати публічні кошти, до інтегральної характеристики спроможності громади до стратегічного розвитку на основі задіяння доступних (централізованих та децентралізованих, публічних і приватних) ресурсів». Тобто категорію спроможності громади пропонується розуміти комплексно, а також відходити від домінуючого тепер патерналістсько-споживацького сприйняття об'єднання громад, яке забезпечує доступ до додаткових бюджетних ресурсів, або - для бідніших громад - до ресурсів багатших сусідів.

3 посиланням на зарубіжні джерела автори аналітичної довідки наголошують, що дієздатність громад базується як на матеріальних (послуги, інфраструктуру, природні ресурси та культурні надбання), так i на нематеріальних (місцеві навички, згуртованість, здатність до дії, адаптивність та відкритість для інших, здатність працювати разом, приймати спільні рішення та втілювати спільне бачення майбутнього розвитку спільноти) активах [13; 17].

Більшою мірою переваги i можливості успішної громади можуть бути реалізовані лише за активної дієвої позиції іiі членів, менеджерів, державних управлінців, громадських активістів. Адже сільські та селищні громади «левову» частку питань місцевого значення не можуть вирішувати самостійно на належному рівні, зокрема, утримувати приміщення та будівлі комунальної власності, здійснювати збір та вивезення (переробку) побутових відходів, будувати та ремонтувати дороги, забезпечувати благоустрій сільських територій та запровадження енергоощадних технологій тощо. Задля цього потрібна консолідація зусиль, ресурсів (в тому числі фінансових), досвіду, знань як в межах громади, так i за іiі межами (район, область, країна, сусідні регіони інших країн при реалізації транскордонного співробітництва).

Більше того, закордонні автори наголошують на важливості участі громади у процесі оцінювання спроможності. Адже наявні неуспішні приклади програм «зверху вниз», які зосереджувались на підзвітності та ефективності, a не на прагненнях громади (Boutilier M., Syme L.). Прикладом є використання «експертів» для вимірювання успіху програми за допомогою заздалегідь визначених контрольних списків показників. Це може віддалити програми від розширення можливостей та розбудови спроможності, оскільки громада не залучається до процесу оцінки [5, С. 487]. «Дуже важливо, щоб робота 3 оцінки спроможності громади не проводилась абстрактно, а через залучення зацікавлених сторін громади, а також через зв'язок оцінки спроможності 3 постійною роботою з трансформації громади» [1].

На нашу думку, серед факторів підвищення спроможності громад важливого значення набуває здатність громад до партнерства та нового рівня співпраці. Її реалізація представляє собою новий досвід, сучасні можливості, рішення та погляди на традиційні (часто консервативні явища і процеси), формування нової філософії та 
культури взаємозв'язків у суспільстві. За умов розбудови ефективної та відповідальної взаємодії влади, громади, бізнесу, неурядового сектору можна говорити про соціально відповідальне партнерство в процесах суспільного розвитку.

Оиінювання партнерських відносин та їx впливу у громадах

Роль регіональних партнерств і спільного регіонального управління у розвитку великих міст досліджували Ssu-Hsien Chen, Richard C. Feiock та Jun Yi Hsieh. Автори визначають регіональні партнерства, як співпрацю у формі кооперативних організацій підрозділів місцевого самоврядування, часто за допомогою третіх сторін (некомерційних та приватних бізнесорганізацій). Однією 3 форм спільного регіонального управління $\epsilon$ самоорганізоване управління через мережі урядів, неурядових приватних організацій та некомерційних організацій, розташованих у різних конфігураціях (Feiock \& Scholz, Parks \& Oakson, Wallis) [3, C. 197]. Щоб відокремити вплив партнерств регіонального економічного розвитку, потрібно врахувати існуючі державні та місцеві фактори, які впливають на розвиток. Чисельність та щільність населення, кількість місцевих органів влади можуть впливати на функцію регіональних партнерств, а також на економічні показники (Basher \&Lagerlof, Working Group on Population Growth and Economic Development, Committee on Population, \& National Research Council). Економія від масштабу при наданні інфраструктурних послуг тісно пов'язана 3 чисельністю населення, щільністю населення та кількістю органів влади, що беруть участь (Henderson) [3, С. 199].

Зупинимось детальніше на елементах, що прямо чи опосередковано пов'язані 3 партнерськими відносинами та співпрацею, а отже, характеризують роль співпраці у спроможності громади. Інтерпретація доменів, наведена Laverack G. у роботі [10] дозволяе прослідкувати взаємозв'язок між наявними доменами, які відображають партнерські відносини у громаді. Cпівучасть є основною для розширення можливостей громади. Через залучення до груп та організацій, окремі члени громади можуть краще визначати, аналізувати та діяти $з$ питань, що становлять загальний інтерес. В свою чергу лідерство базується на сильній співучасті, а співучасть вимагає керівництва та сильного лідерства. Організаиійні структури в громаді включають невеликі групи, такі як комітети, релігійні та молодіжні групи тощо. Це організаційні елементи, які представляють способи об'єднання людей для спілкування та вирішення своїх проблем. Наявність та активність цих організацій є вирішальним для розширення можливостей громади. Зв'язки з людьми та організаиіями, включаючи партнерства, коаліції та добровільні союзи між громадою та іншими, можуть допомогти громаді у вирішенні іiі проблем. Зовнішні агенти у контексті програм часто $\epsilon$ важливою ланкою між громадами та зовнішніми ресурсами. Їх роль $\epsilon$ визначальною при ініціації певних програм розвитку громади. Зовнішній агент трансформує владні відносини таким чином, що громада бере на себе все більші повноваження в програмі [5, С. 487].

У США в рамках проєктів Evaluation of Healthy Kids, Healthy Communities за допомогою 82позиційного інструментарію було проведено обстеження партнерств і спроможності громади, оцінено перспективи учасників і представників громад щодо структури та функцій їх партнерських відносин та спроможності громади до змін [7]. За допомогою факторного аналізу та описової статистики описано загальні характеристики партнерських відносин, їх керівництво та їхні взаємозв'язки 3 громадами. Обстеження дозволило виділити 15 факторів, зокрема лідерство, структуру партнерства, відносини 3 партнерами, потенціал партнера, політичний вплив партнерства та сприйняття взаємодії партнерства з громадою та її членами.

Також у літературі описано такі елементи функціонування партнерства, які впливають на здатність співпраці досягати високих рівнів синергії: 1) ресурси: гроші, площа, обладнання, товари, навички та досвід, інформація, зв'язки 3 людьми, організаціями, групами, рекомендації, залучення влади; 2) характеристика партнера: неоднорідність, рівень залученості; 3) відносини між партнерами: довіра, повага, конфлікт, диференціація можливостей; 4) характеристика партнерства: лідерство, адміністрування та менеджмент, управління, ефективність; 5) зовнішнє середовище: характеристика громади, державна та організаційна політика [9, С. 189]. Вивчення таких інструментів дозволяє виміряти наскільки партнерства досягають синергії, відрізнити партнерства, що досягають високих рівнів синергії, від тих, які цього не роблять, i безпосередньо перевірити основне припущення про переваги співпраці над сукупністю зусиль, що здійснюють окремо потенційні учасники партнерств.

Xueqing Zhang, оцінюючи успіх проектів державно-приватного партнерства, виокремив 5 основних критичних факторів (та підфактори до кожного 3 них) успіху. Респонденти оцінювали значимість цих факторів за шкалою 0-5. П'ять основних критичних факторів успіху: 1) 
сприятливе інвестиційне середовище; 2) економічна життєздатність; 3) надійне партнерство 3 потужними технічними можливостями; 4) безпечний фінансовий пакет; 5) належний розподіл ризиків за допомогою надійних договірних домовленостей [15, С.4].

Такі методи оцінювання успіху чи синергії співпраці хоч і враховують зовнішні фактори, проте оцінюють партнерство в основному відокремлено і не визначають його впливу на розвиток громади, а також не дають можливості оцінити партнерську спроможність громади.

R.D. Lasker, E.S. Weiss та R. Miller досліджують поняття синергії партнерства та ідентифікують ऑiі як найближчий результат функціонування партнерства, що, в свою чергу, робить співпрацю особливо ефективною [9, С. 184]. Враховуючи труднощі, які виникають у процесі співпраці, цілком ймовірно, що багато партнерів не досягають високого рівня синергії. Однак, на даний час неможливо визначити, якою мірою досягається синергія, оскільки ще ніхто не розробив спосіб іiі визначення. Скоріш за все, такої точної міри не існує, адже «розроблені методи оцінювання, як правило, фокусуються на окремих компонентах спільних зусиль .... Ці фрагментовані або епізодичні оцінки можуть пропустити ефекти взаємодії між людьми, перспективи та програми, що позначають справжню цінність співпраці» [14].

3 урахуванням вищевикладеного, можемо окреслити таке трактування партнерської спроможності. Партнерська спроможність громад - це їх здатність до активної взаємодії з різними суб'єктами-партнерами (іншими громадами, бізнесом та неурядовим (громадським) сектором) на договірних засадах у різних сферах суспільноекономічного життя шляхом об'єднання й координації зусиль, ресурсів, в тому числі фінансових, рівної участі кожної зі сторін та спільної відповідальності за результати діяльності з метою досягнення спільних цілей. Вкрай важливою для цього $є$ наявність активно налаштованої частини членів територіальної громади, що беруть участь у вирішенні різних проблем іiі життєдіяльності та готові нести відповідальність за прийняті рішення й реалізовані заходи. Усвідомлення вагомості партнерських відносин повинно зростати разом із розумінням проблем нестачі ресурсів та більш ефективного їх використання, недостатнього інфраструктурного забезпечення, обмеженого доступу до інноваційних технологій чи складних технологічних процесів, що притаманно для кожної окремої громади, особливо в сільській місцевості, і може бути подолано через партнерську взаємодію.

Labonte \& Laverack дали визначення формування партнерської спроможності як «збільшення у громаді можливостей груп визначати, оцінювати, аналізувати та впливати на ... проблеми, що мають важливе значення для членів громади» [8, С. 114]. Спроможність групи також залежить від ресурсних можливостей або обмежень (економічних, політичних, екологічних) та умов, в яких живуть люди і групи [5, C. 485].

Отже, процес дослідження і розвитку підходів до обгрунтування сутності та виявлення громад, спроможних до партнерства, викликає потребу вибору та оцінювання параметрів такої спроможності. По перше, доцільно виявити рівень ресурсного та інфраструктурного забезпечення громади, достатність іiі кадрового потенціалу. Без цього вона не в змозі ставати рівноправним дієвим партнером, набувати статусу активного та впливового учасника. Для визначення громадської і суспільно значимої діяльності важливо оцінити наявність у ній лідерів, їх готовність до ініціювання нових проектів і відповідальності за їх реалізацію, існування громадських організацій, створюваних не лише задля втілення якихось одиничних цілей і заходів, важливих для окремих цільових груп, а для системної роботи i досягнення важливих результатів для громади в цілому. Велике значення має попередньо накопичений досвід партнерської взаємодії (укладені формалізовані договори, підписані меморандуми 3 іншими громадами, бізнесовими структурами, громадськими організаціями, приклади неформальних (усних) контактів, які сприяють вирішенню суспільно значимих проблем).

Представлені практичні рекомендації 3 визначення потенційних партнерів i налагодження партнерських зв'язків для бізнесу, що містять шість параметрів [20], після певної видозміни можна застосовувати $\mathrm{i}$ для рівня територіальних громад. Урахування додаткових характеристик, які відображають нематеріальні компоненти партнерської спроможності (згуртованість, довіра і самоорганізація, спільне бачення, стратегічний план розвитку), дає можливість визначати та оцінювати партнерську спроможність громад за такими параметрами (табл.1). 
Таблиця 1

Характеристики громади, спроможної до партнерства*

\begin{tabular}{|c|c|}
\hline $\begin{array}{l}\text { Параметри } \\
\text { спроможності до } \\
\text { партнерства }\end{array}$ & Сутнісна характеристика індикатора / громади \\
\hline $\begin{array}{l}\text { Місія, цілі } \quad \text { та } \\
\text { цінності громади, } \\
\text { стратегічний план } \\
\text { розвитку }\end{array}$ & $\begin{array}{l}\text { Громада повинна чітко і зрозуміло формулювати свої цінності та місію, а також цілі } \\
\text { проекту, який планується реалізовувати через партнерство. Підгрунтям цього стають } \\
\text { стратегічні документи розвитку громади (стратегія і плани соціально-економічного } \\
\text { розвитку), в яких представлено обгрунтовані та прозорі перспективи, в тому числі на } \\
\text { довгострокових горизонтах, шляхи і ресурси для їх досягнення }\end{array}$ \\
\hline Потенціал громади & $\begin{array}{l}\text { Загальна сукупність ресурсів і можливостей громади (природних, матеріальних, } \\
\text { фінансових), відповідне кадрове забезпечення, а також досвід, навички, лідерські } \\
\text { характеристики. Весь комплекс ресурсного потенціалу даватиме можливість брати } \\
\text { активну участь у реалізації партнерських проектів }\end{array}$ \\
\hline $\begin{array}{l}\text { Репутація громади, } \\
\text { достовірність } \\
\text { інформації про неї і } \\
\text { довіра }\end{array}$ & $\begin{array}{l}\text { Репутація важлива в контексті розвитку та налагодження нових зв'язків і пошуку } \\
\text { нових партнерів. Висока репутація кожного наступного разу сприятиме прискоренню } \\
\text { та підвищенню результативності укладання нових партнерських угод і реалізації } \\
\text { успішних проектів. Прозора та повна інформація про громаду, їі проекти є важливою } \\
\text { для потенційних партнерів, а приховування та викривлення інформації руйнує } \\
\text { довірливі стосунки, призводить до непорозумінь, викликає конфлікти, результатом } \\
\text { чого ставатиме зниження ефективності або навіть розірвання партнерських відносин. }\end{array}$ \\
\hline $\begin{array}{lr}\text { Заінтересованість } \\
\text { громади } \\
\begin{array}{l}\text { партнерстві } \\
\text { реалізації проекту }\end{array}\end{array}$ & $\begin{array}{l}\text { Без інтересу, який може втілюватись в конкретних результатах (ремонт, будівництво } \\
\text { нового об'єкту, проведення культурного, освітнього, просвітницького, спортивного } \\
\text { тощо заходу), громада не матиме стимулу до взаємодії та укладання партнерських } \\
\text { угод. Спільні інтереси ставатимуть для потенційних партнерів точками дотику, за } \\
\text { якими варто реалізовувати партнерські відносини }\end{array}$ \\
\hline $\begin{array}{l}\text { Згуртованість } \\
\text { громади, } \\
\text { самоорганізація іiі } \\
\text { членів (громадянська } \\
\text { участь) }\end{array}$ & $\begin{array}{l}\text { Через самоорганізацію, згуртованість громади як здатність ії членів співпрацювати } \\
\text { разом, об’єднуватись задля виконання певних завдань і реалізації цілей, громада } \\
\text { посилює свій потенціал і спроможність у вирішенні проблем спільного проживання. } \\
\text { Це призводить до появи нових «свіжих» ідей, сприяє реалізації синергетичних ефектів, } \\
\text { формує відповідальну поведінку членів громади, усвідомлення своєї значимості у } \\
\text { громадському житті, має вплив на особистісний розвиток мешканців, підвищення іхх } \\
\text { соціальної та громадянської компетентності та активності }\end{array}$ \\
\hline $\begin{array}{l}\text { Структура } \\
\text { управління } \\
\text { характеристика } \\
\text { менеджменту } \\
\text { громади }\end{array}$ & $\begin{array}{l}\text { Під цим параметром, на відміну від кадрового потенціалу громади, мається на увазі } \\
\text { ефективність управлінських структур громади в цілому, а також професіоналізм, } \\
\text { відповідальність і лідерські характеристики конкретних менеджерів, лідерів, що } \\
\text { закріплюються за тими чи іншими проектами, заходами, акціями в рамках } \\
\text { партнерства. }\end{array}$ \\
\hline Оцінка ризиків & $\begin{array}{l}\text { Оцінка ризиків, притаманних саме для цієї громади в частині їі участі в тому чи іншому } \\
\text { проекті / партнерстві. Доцільно оцінювати різні види ризиків, пов’язані } \\
\text { функціонуванням громади та реалізацією проектів (управлінські, організаційні, } \\
\text { фінансові, екологічні) }\end{array}$ \\
\hline
\end{tabular}

*Складено та розвинуто авторами за джерелами: $[2 ; 5 ; 6 ; 7 ; 9 ; 11 ; 13 ; 16 ; 20]$.

Наведені параметри спроможності громад до партнерства, наприклад, в частині іiі потенціалу, можуть бути оцінені кількісно за допомогою відповідних показників природного, інфраструктурного, фінансового забезпечення. Місія, цілі, цінності громади відображаються в стратегічних документах ऑii розвитку, тому важливим слід визнати професіоналізм і повноту ïх розробки. Інші параметри потрібно оцінювати якісно через додаткове аналізування нематеріальних «активів» громади, до яких належать репутація, згуртованість, заінтересованість громади, структура управління тощо.

Висновки i перспективи подальших досліджень. Світовий досвід засвідчує, що все частіше для підвищення потенціалу громад створюються партнерства, в результаті чого спроможність таких громад зростає за рахунок об'єднання їх активів та специфічних особливостей. Розвиток партнерської спроможності сприяє збільшенню можливостей різних громадських груп i громад у цілому визначати, оцінювати, аналізувати та впливати на стан будь-якої проблеми, що має важливе соціально-економічне значення для всіх або більшості членів громади.

За сучасних умов в Україні також зростає значимість партнерської спроможності громад, яка передбачає їх здатність до активної взаємодії 3 різними партнерами задля вирішення суспільно значущих питань і проблем, реалізації соціальних 
проєктів. Без сумніву, серед факторів використовувати при здійсненні оцінки становлення та зростання партнерської партнерської спроможності громад, що стає спроможності важливим $є$ ресурсно- важливим на етапі розбудови різних видів інфраструктурне забезпечення, проте не менш значимими слід визнати фактори та умови нематеріального змісту, до яких віднесено місію, цілі та стратегічні плани розвитку громади, іiі заінтересованість, згуртованість та самоорганізацію, репутацію громади та довіру до неї. Саме ці групи факторів (матеріальні та нематеріальні), трансформовані у відповідні показники чи параметри, доцільно

партнерських відносин.

Перспективи подальших досліджень у даному напрямку можуть стосуватися розробки конкретизованої методики оцінки партнерської спроможності громади 3 урахуванням не тільки окремих факторів, але і взаємозв'язків між ними, а також апробації сформованої методики за реальних умов новостворених об'єднаних територіальних громад у Закарпатській області.

\section{ПЕРЕЛІК ВИКОРИСТАНИХ ДЖЕРЕЛ}

1. Bopp, M., \& Bopp, J. (2004). Welcome to the swamp: Addressing community capacity in ecohealth research and intervention. EcoHealth, 1(2), 24-34.

2. Bowen, G. L., Martin, J. A., Mancini, J. A., \& Nelson, J. P. (2000). Community Capacity. Journal of Community Practice, 8(2), 1-21.

3. Chen, S.-H., Feiock, R. C., \& Hsieh, J. Y. (2016). Regional Partnerships and Metropolitan Economic Development. Journal of Urban Affairs, 38(2), 196-213.

4. Gibbon, M. (1999). Meetings with meaning: health dynamics in rural Nepal (Doctoral dissertation, South Bank University).

5. Gibbon, M., Labonte, R., \& Laverack, G. (2002). Evaluating community capacity. Health and Social Care in the Community, 10(6), 485-491.

6. Goodman, R. M., Speers, M. A., McLeroy, K., Fawcett, S., Kegler, M., Parker, E., Smith, S. R., Sterling, T. D., \& Wallerstein, N. (1998). Identifying and defining the dimensions of community capacity to provide a basis for measurement. Health Education \& Behavior, 25(3), 258-278.

7. Kemner, A. L., Donaldson, K. N., Swank, M. F., \& Brennan, L. K. (2015). Partnership and Community Capacity Characteristics in 49 Sites Implementing Healthy Eating and Active Living Interventions. Journal of Public Health Management and Practice, 21, 27-33.

8. Labonte, R., \& Laverack, G. (2001). Capacity building in health promotion, Part 1: For whom? And for what purpose? Critical Public Health, 11(2), 111-127.

9. Lasker, R. D., Weiss, E. S., \& Miller, R. (2001). Partnership Synergy: A Practical Framework for Studying and Strengthening the Collaborative Advantage. The Milbank Quarterly, 79(2), 179-205.

10. Laverack, G. (1999). Addressing the contradiction between discourse and practice in health promotion (No. $\mathrm{Ph}$.

D.). Deakin University.

11. Laverack, G. (2005). Evaluating community capacity: Visual representation and interpretation. Community Development Journal, 41(3), 266-276.

12. Maclellan-Wright, M. F., Anderson, D., Barber, S., Smith, N., Cantin, B., Felix, R., \& Raine, K. (2007). The development of measures of community capacity for community-based funding programs in Canada. Health Promotion International, 22(4), 299-306.

13. OECD (2016), OECD Regional Outlook 2016: Productive Regions for Inclusive Societies, OECD Publishing, Paris. 14. Taylor-Powell, E., Rossing, B., \& Geran, J. (1998). Evaluating collaboratives: Reaching the potential. Program Development and Evaluation, Madison, WI: University of Wisconsin Extension.

15. Zhang, X. (2005). Critical Success Factors for Public-Private Partnerships in Infrastructure Development. Journal of Construction Engineering and Management, 131(1), 3-14.

16. Бриль, М., Врублевський, О., Данчева, О., Сеїтосманов, А. \& Чубаров, Е. (2018). Успішна територіальна громада: будуємо разом. Харків: Видавничий будинок Фактор. URL: https://despro.org.ua/library/publication/UspishnaTerytorialnaHromada2018.pdf.

17. Жаліло, Я. А., Шевченко, О. В., Романова, В. В. та ін. (2019). Децентралізація влади: порядок денний на середньострокову перспективу (Аналітична доповідь). Київ: Національний інститут стратегічних досліджень. URL: https://niss.gov.ua/sites/default/files/2019-05/2019.pdf.

18. Про добровільне об'єднання територіальних громад (2015): Закон України № 157-VIII. URL: https://zakon.rada.gov.ua/laws/show/157-19\#Text.

19. Про затвердження Методики формування спроможних територіальних громад (2015): Постанова КМУ № 214. URL: https://zakon.rada.gov.ua/laws/show/214-2015-\%D0\%BF\#n10.

20. Як налагодити партнерство: рекомендації для бізнесу (2010). URL: https://issuu.com/csrcentre/docs/.

\section{REFERENCES}

1. Bopp, M., \& Bopp, J. (2004). Welcome to the swamp: Addressing community capacity in ecohealth 
research and intervention. EcoHealth, 1(2), 24-34.

2. Bowen, G. L., Martin, J. A., Mancini, J. A., \& Nelson, J. P. (2000). Community Capacity. Journal of Community Practice, 8(2), 1-21.

3. Chen, S.-H., Feiock, R. C., \& Hsieh, J. Y. (2016). Regional Partnerships and Metropolitan Economic Development. Journal of Urban Affairs, 38(2), 196-213.

4. Gibbon, M. (1999). Meetings with meaning: health dynamics in rural Nepal (Doctoral dissertation, South Bank University).

5. Gibbon, M., Labonte, R., \& Laverack, G. (2002). Evaluating community capacity. Health and Social Care in the Community, 10(6), 485-491.

6. Goodman, R. M., Speers, M. A., McLeroy, K., Fawcett, S., Kegler, M., Parker, E., Smith, S. R., Sterling, T. D., \& Wallerstein, N. (1998). Identifying and defining the dimensions of community capacity to provide a basis for measurement. Health Education \& Behavior, 25(3), 258-278.

7. Kemner, A. L., Donaldson, K. N., Swank, M. F., \& Brennan, L. K. (2015). Partnership and Community Capacity Characteristics in 49 Sites Implementing Healthy Eating and Active Living Interventions. Journal of Public Health Management and Practice, 21, 27-33.

8. Labonte, R., \& Laverack, G. (2001). Capacity building in health promotion, Part 1: For whom? And for what purpose? Critical Public Health, 11(2), 111-127.

9. Lasker, R. D., Weiss, E. S., \& Miller, R. (2001). Partnership Synergy: A Practical Framework for Studying and Strengthening the Collaborative Advantage. The Milbank Quarterly, 79(2), 179-205.

10. Laverack, G. (1999). Addressing the contradiction between discourse and practice in health promotion (No. Ph. D.). Deakin University.

11. Laverack, G. (2005). Evaluating community capacity: Visual representation and interpretation. Community Development Journal, 41(3), 266-276.

12. Maclellan-Wright, M. F., Anderson, D., Barber, S., Smith, N., Cantin, B., Felix, R., \& Raine, K. (2007). The development of measures of community capacity for community-based funding programs in Canada. Health Promotion International, 22(4), 299-306.

13. OECD (2016), OECD Regional Outlook 2016: Productive Regions for Inclusive Societies, OECD Publishing, Paris.

14. Taylor-Powell, E., Rossing, B., \& Geran, J. (1998). Evaluating collaboratives: Reaching the potential. Program Development and Evaluation, Madison, WI: University of Wisconsin Extension.

15. Zhang, X. (2005). Critical Success Factors for Public-Private Partnerships in Infrastructure Development. Journal of Construction Engineering and Management, 131(1), 3-14.

16. Bryl', M., Vrublevs'kyj, O., Dancheva, O., Seitosmanov, A. \& Chubarov, E. (2018). Uspishna terytorial'na hromada: buduiemo razom [Successful territorial community: we build together]. Kharkiv: Vydavnychyj budynok Faktor. Retrieved from https://despro.org.ua/library/publication/UspishnaTerytorialnaHromada2018.pdf [in Ukrainian].

17. Zhalilo, Ya. A., Shevchenko, O. V., Romanova, V. V. et al. (2019). Detsentralizatsiia vlady: poriadok dennyj na seredn'ostrokovu perspektyvu (Analitychna dopovid') [Decentralization of power: an agenda for the medium term (Analytical report)]. Kyiv: National Institute for Strategic Studies. Retrieved from https://niss.gov.ua/sites/default/files/2019-05/2019.pdf [in Ukrainian].

18. Pro dobrovil'ne ob'iednannia terytorial'nykh hromad [On voluntary association of territorial communities] (2015): Law of Ukraine № 157-VIII. Retrieved from https://zakon.rada.gov.ua/laws/show/157-19\#Text [in Ukrainian].

19. Pro zatverdzhennya Metodyky formuvannya spromozhnykh terytorial'nykh hromad [On approval of the Methodology of establishment of capable territorial communities] (2015): Resolution of the Cabinet of Ministers of Ukraine № 214. Retrieved from https://zakon.rada.gov.ua/laws/show/214-2015-\%D0\%BF\#n10 [in Ukrainian].

20. Yak nalahodyty partnerstvo: rekomendatsii dlia biznesu [How to build a partnership: recommendations for business] (2010). Retrieved from https://issuu.com/csrcentre/docs/ [in Ukrainian].

Отримано 22.02.2021 